\title{
FIRST STEGOSAURIAN DINOSAUR REMAINS FROM THE EARLY CRETACEOUS OF BURGOS (SPAIN), WITH A REVIEW OF CRETACEOUS STEGOSAURS
}

\author{
Xabier PEREDA SUBERBIOLA ${ }^{1}$, Peter $M$. \\ GALTON ${ }^{2}$, Fidel TORCIDA ${ }^{3}$, Pedro HUERTA ${ }^{3}$, \\ Luis Ángel IZQUIERDO ${ }^{3}$, Diego MONTERO ${ }^{3}$, \\ Gustavo PÉREZ ${ }^{3}$ and Víctor URIÉN ${ }^{3}$ \\ ${ }^{1}$ Universidad del País Vasco/EHU, Facultad de Ciencias, Departamento de \\ Estratigrafía y Paleontología, Apdo. 644, 48080 Bilbao. gpppesuf@lg.ehu.es \\ ${ }^{2}$ College of Naturopathic Medicine, University of Bridgeport, Bridgeport, CT \\ 06601-2449 (USA).pgalton@juno.com \\ ${ }^{3}$ Museo de Dinosaurios y Colectivo Arqueológico-Paleontológico de Salas \\ (C.A.S.), Plaza Jesús Aparicio, 9, 09600 Salas de los Infantes (Burgos, Spain). \\ museodesalas@salasdelosinfantes.net y ftof0000@enebro.pntic.mec.es
}

Pereda Suberbiola, X., Galton, P.M., Torcida, F., Huerta, P., Izquierdo, L.A., Montero, D., Pérez, G. and Urién, V. 2003. First Stegosaurian Dinosaur remains from the Early Cretaceous of Burgos (Spain), with a review of Cretaceous stegosaurs. [Primeros restos de Dinosaurios Estegosaurios en el Cretácico Inferior de Burgos (España). Revisión de los estegosaurios cretácicos.] Revista Española de Paleontología, 18 (2), 143-150. ISSN 0213-6937.

\begin{abstract}
Stegosaurian remains from the Early Cretaceous (Wealden beds, probably Hauterivian-Barremian) of Aldea del Pinar (Burgos, Spain) are described. The material consists of the ?most posterior dorsal vertebra and a partial dermal plate. The general form of the vertebra, with a massive centrum, a prominent lateral depression and solid neural arch pedicels, is reminiscent of the dorsal vertebrae of Dacentrurus, but the centrum is even more massive than in this genus from the Late Jurassic. Pending the discovery of new fossils, the Burgos material is provisionally referred to as Stegosauria indeterminate. This is the first report of stegosaurs in the region of Castilla y León and one of the few records of this group of thyreophoran dinosaurs from the Early Cretaceous of Europe. The occurrence of other Cretaceous stegosaurs is reviewed.
\end{abstract}

Keywords: Dinosauria, Stegosauria, Early Cretaceous, Burgos, Spain.

\section{RESUMEN}

Se describen restos fósiles de estegosaurio provenientes del Cretácico Inferior (facies Weald, atribuido al Hauteriviense-Barremiense) de Aldea del Pinar (Burgos, España), que consisten en una vértebra dorsal posterior (probablemente la última dorsal) y una placa dérmica incompleta. El aspecto general de la vértebra, con un centro robusto, una concavidad lateral marcada y la solidez de los pedicelos del arco neural, es comparable al de las vértebras dorsales de Dacentrurus, aunque el centro es incluso más masivo que en este género del Jurásico Superior. A la espera de descubrir nuevos fósiles, el material de Burgos se asigna provisionalmente a un Stegosauria indeterminado. Se trata de la primera cita de un estegosaurio en Castilla y León y una de las escasas menciones de este grupo de dinosaurios tireóforos en el Cretácico Inferior de Europa, como evidencia la revisión del registro de los estegosaurios cretácicos.

Palabras clave: Dinosauria, Stegosauria, Cretácico Inferior, Burgos, España. 


\section{INTRODUCTION}

Stegosaurian dinosaurs from the Iberian Peninsula are represented by fragmentary remains, with a few partial skeletons (Pereda Suberbiola and Galton, 2001). Most of these remains come from the Upper Jurassic continental beds of the coastal region near Lourinha, central western Portugal (see Lapparent and Zbyszewski, 1957; Galton, 1981, 1990a, 1991), but other material occurs in the Upper Jurassic (or basal Cretaceous) deposits of the Los Serranos area, Valencia, eastern Spain (Casanovas et al., 1995a, 1995b, 1997, 1999). All these remains, which consist of postcranial bones and dermal armour, have been referred to Dacentrurus armatus (Owen, 1875), a basal stegosaur well represented in the Upper Jurassic rocks of England and France (see Galton, 1985, 1991 and references therein).

Wealden stegosaurs in the Iberian Peninsula are very rare. Only a dermal spine of an indeterminate stegosaur has been mentioned as occurring in the Hauterivian rocks of Galve (Teruel) (Pereda Suberbiola and Galton, 2001) and some vertebral remains have been reported to as ?Stegosauria indet. from the Barremian-Aptian of Castellote (Teruel) (Ruiz-Omeñaca, 2000). The aim of this paper is to describe new stegosaurian remains from the Wealden beds of Burgos, Spain. This is the first report of this group of dinosaurs in the region of Castilla y León.

Abbreviation: PS, Museo de Dinosaurios, Paleontología, Salas de los Infantes, Burgos, Spain.

\section{GEOLOGICAL SETTING}

The stegosaurian remains described below were discovered at Aldea del Pinar (Tenada Tizuela locality), near Salas de los Infantes (Burgos, Spain) (Fig. 1, left). They consist of a dorsal vertebra (PS-TZA,20) and a dermal plate (PSTZA,17), both incomplete. The remains were unearthed from a field under cultivation. The substratum is composed of red clays as can also be observed in adjacent outcrops. The fossils were not found in situ but not far from each other, and probably come from the same level. It is unlikely

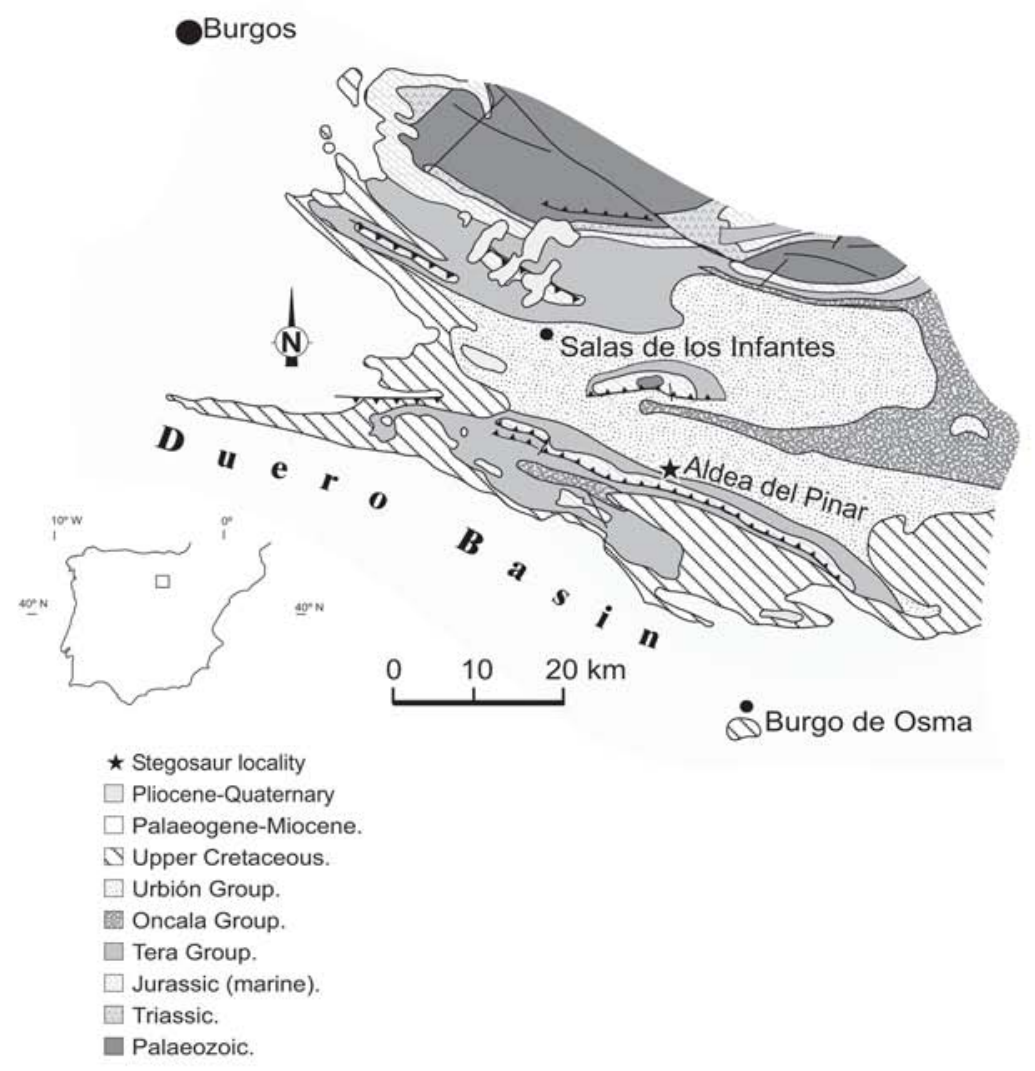

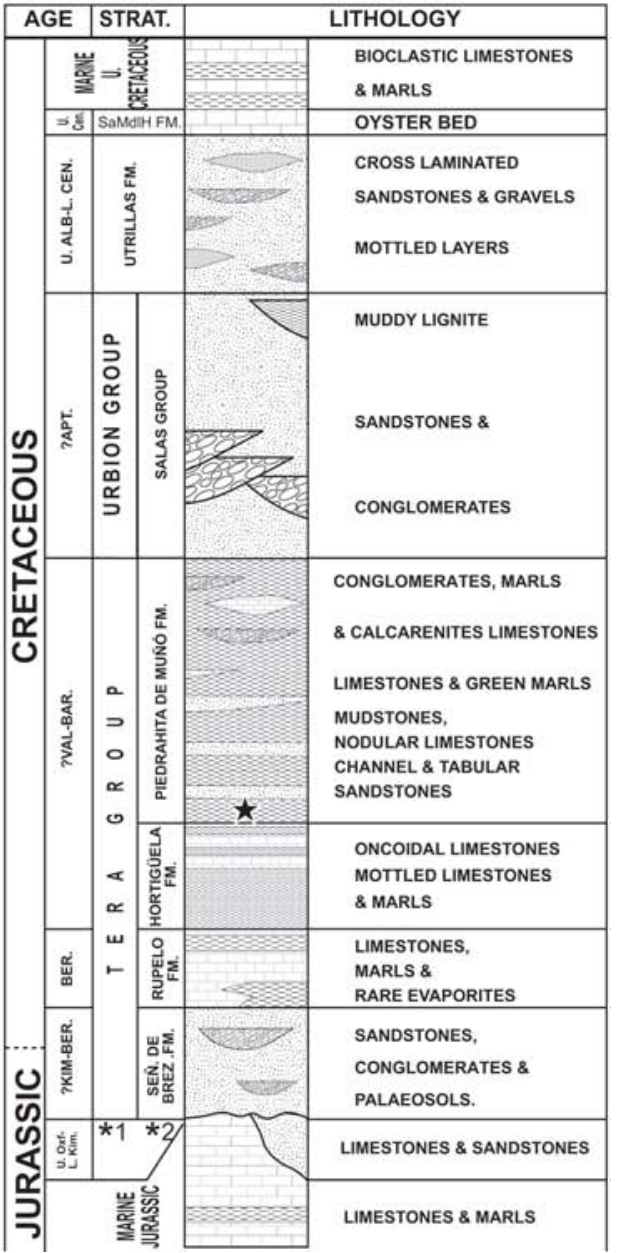

Figure 1. Geological map of the western Cameros Basin showing the stegosaurian locality, and stratigraphical column of the Salas de los Infantes area (Burgos, Spain). Modified from Beuther (1966) and Platt (1986). Stratigraphical division: *1) from Beuther (1966), *2) from Platt (1989). Abbreviations: SaMdlH FM = Santa María de las Hoyas Formation; SEN. DE BREZ. FM. = Señora de los Brezales Formation. 
that they have been reworked from older marine Jurassic deposits as the diagenetic features suggest that the burial occurred in a continental alluvial plain that was affected by carbonatation and rubefaction processes. Other dinosaur bones from the same locality consist of a few caudal vertebrae of an ankylosaur. All these remains are kept in the Museo Paleontológico de Salas de los Infantes, Burgos.

The fossiliferous site is located to the southeast of the town of Aldea del Pinar. The beds belong to the Tera Group (Beuther, 1966), which is represented in this area by the Piedrahita de Muñó Formation (Platt, 1986) (see Fig. 1, right). This formation is equivalent to the Pinilla de los Moros Formation of the western Cameros Basin (Clemente and Pérez-Arluzea, 1993), which is Late Hauterivian-Early Barremian in age (sensu Martín Closas and Alonso Millán, 1998). Following Platt (1986), the Piedrahita de Muñó Formation is ?Valanginian-Barremian as its lower boundary is uncertainly known. The sedimentological features have been studied in an outcrop nearby to the area where the fossils were found. The unit, about $230 \mathrm{~m}$ thick, is composed of reddish lutites, calcretes, lithic sandstones and conglomerates with clasts less than $2 \mathrm{~cm}$. These deposits are of distal alluvial origin. The bed strike is NW-SE, with a dip of $30^{\circ} \mathrm{N}$. The thickness of the sandstone beds varies from 10 to 1500 $\mathrm{cm}$. They show tabular geometries that can disappear laterally. The sandstones show internal planar and trough cross-bedding, and they contain lutite intraclasts at the bottom. Interbedded with the sandstones are layers of red lutite, $30-200 \mathrm{~cm}$ thick, with generally nodular calcretes.

\section{SYSTEMATIC PALAEONTOLOGY}

\section{DESCRIPTION}

Dorsal vertebra (Figs. 2A-C): An isolated, incomplete dorsal vertebra is known. It preserves part of the centrum, including most of one articular surface and the central part of the other, and the basal region of the neural arch. Just above the neural canal, the neural pedicel is indented by a groove whereas the other end shows a median ridge. Comparisons with the available figures of the dorsal vertebrae of Dacentrurus Lucas, 1902 (see Owen, 1875; Galton, 1985) indicate that these conditions cannot clearly be used to identify which end is which. In most dorsals of Stegosaurus the groove on the pedicel is anterior and the ridge posterior (Ostrom and McIntosh, 1966, 1999), so, if this was also true for this vertebra, then the most complete articular surface was posterior (Fig 2B, C). The maximum preserved length of the centrum is $40 \mathrm{~mm}$. The preserved articular surface is slightly concave and the width ( $95 \mathrm{~mm}$ as preserved) is greater than the height (about $75 \mathrm{~mm}$ ). Only the central part of the other articular surface is preserved and the concavity is visible in lateral view (Fig. 2C). Laterally, the part of the centrum adjacent to the neural canal is pinched in to form a prominent depression. There is no evidence of the neurocentral suture, which may indicates that this is an adult individual or it is a function of preservation. As preserved, the neural canal is wider $(30 \mathrm{~mm})$ than high $(25 \mathrm{~mm})$ at one end and the reverse at the other ( $28 \mathrm{~mm}$ by $35 \mathrm{~mm}$ ). The pedicel region of the neural arch is broken but it appears to be columnar-like and massive. There is no evidence of the parapohyses, which were probably superior to the preserved part of the pedicel.

Dermal plate (Figs. 2D-F): As preserved, the dermal plate is subrectangular in lateral or medial view, being twice as long as high, but the apical part of the plate is missing. The plate is asymmetrical with the anterior and posterior borders obliquely inclined posterodorsally, so the posterior border extends beyond the base. The maximum anteroposterior length of the plate is about $250 \mathrm{~mm}$ with at least $30 \mathrm{~mm}$ lacking from the anterior tip; the maximum preserved vertical height is $125 \mathrm{~mm}$. Dorsally, the plate has a thickness of 20 to $30 \mathrm{~mm}$ in cross-section. Judging from the asymmetry in anterior or posterior views (Fig. 2E), the plate is from the left side. The lateral and medial sides are rugose, the former moderately concave and the latter gently convex. The base is lenticular, almost three times longer than wide (maximum basal length $180 \mathrm{~mm}$; maximum transverse thickness near the middle of the base $65 \mathrm{~mm}$ ). The ventral surface is flat to slightly concave, with small subcircular pits.

\section{DISCUSSION}

The general form of the vertebra suggests that it came from the dorsal region. It resembles the dorsal vertebrae of the stegosaur Dacentrurus armatus (Owen, 1875) from the Late Jurassic (and basal Cretaceous?) of western Europe (see Galton, 1985: figs. 6B, 6F, 7C, 16S; Galton, 1991: fig. 3 from Nopcsa, 1911). The massiveness of the centrum, the prominent lateral depression on each side of the centrum and the solid pedicel-like region of the neural arch are reminiscent of these of the dorsal vertebrae of Dacentrurus from England, France and Portugal. However, the centrum appears to be even more massive than those of Dacentrurus, with the maximum transverse width greatly exceeding the length of the centrum (possibly indicating that this is the most posterior dorsal vertebra). In contrast, other stegosaurs have more "stretched" vertebrae, with less massive centra, less prominent lateral depressions and more slender pedicels of the neural arch (Galton, 1985, 1990a, 1991).

The exact position of the dermal plate above the vertebral column in unknown. It roughly resembles the dorsal plates of Lexovisaurus Hoffstetter, 1957 (see Galton, 1985, 1990b) and Kentrosaurus Hennig, 1915 (see Galton, 1982), so it could come from the dorsal region. The specimen has a moderately expanded base as in the fifth dermal plate of Kentrosaurus (Galton, 1982: pl. 1, figs. 3-4), a dorsal plate of Lexovisaurus (Galton, 1985: figs. 18MQ) and a presacral plate of Tuojiangosaurus Dong et al., 1977 (Dong et al., 1977: fig. 5, pl. 2, fig. 2). In contrast, the bases of the plates of Stegosaurus Marsh, 1877 (Gilmore, 1914; Ostrom and McIntosh, 1966, 1999) and Hesperosaurus Carpenter et al., 2001 are greatly thickened. The Burgos specimen differs from the dorsal plates of Kentrosaurus in that it is comparatively more elongate and does not have a large lateral flange, and from those 

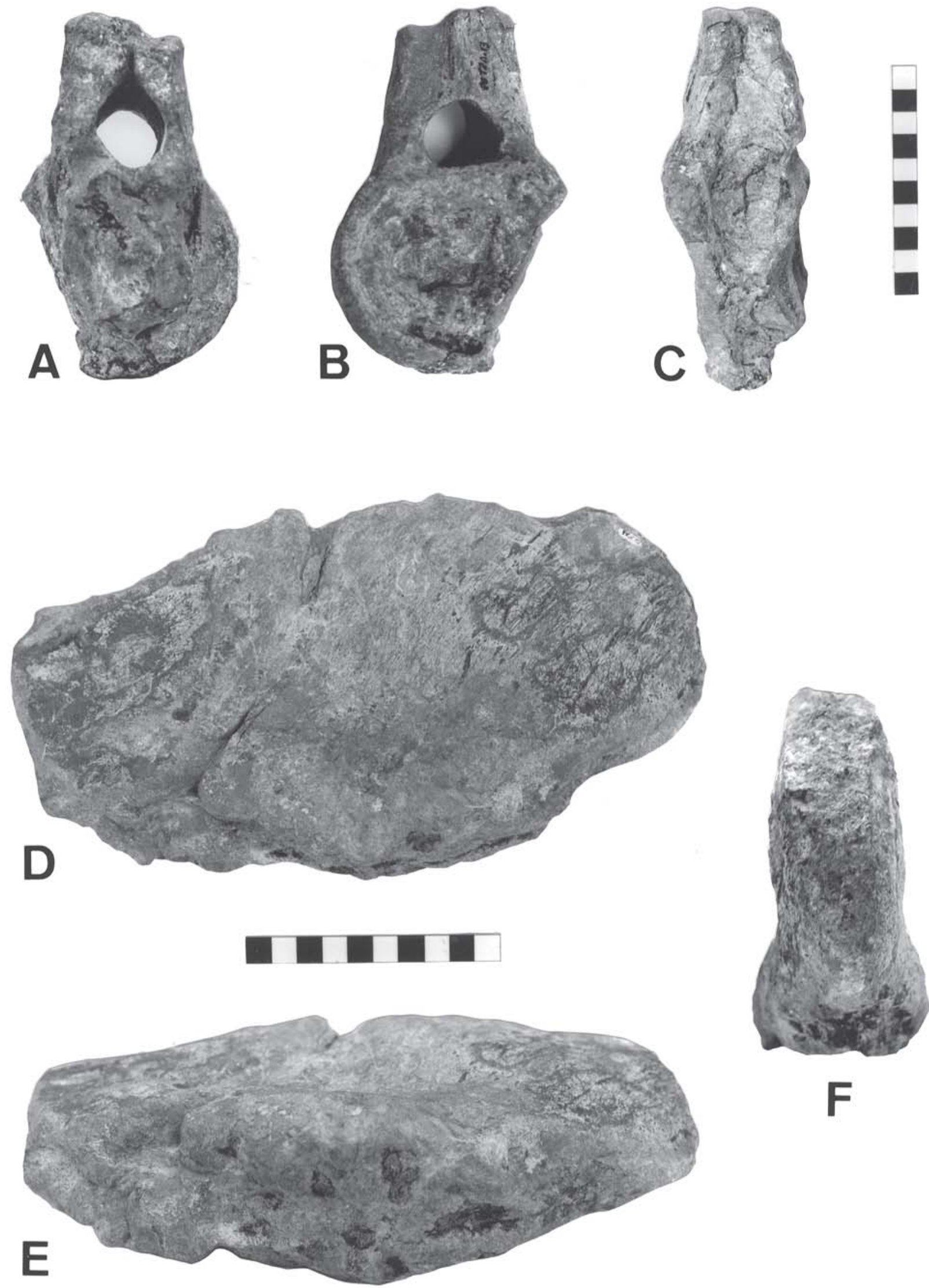

Figure 2. Stegosauridae indet., Early Cretaceous of Aldea del Pinar, near Salas de los Infantes, Burgos, Spain. A-C, PS-TZA,20, ?most posterior dorsal vertebra in ?anterior (A), ?posterior (B) and ?right lateral (C) views; D-F, PS-TZA, 17, partial left dorsal plate in left lateral (D), ventral (E) and posterior (F) views. In D and E, the anterior side of the plate is on the left and the posterior side on the right. Scale $=100 \mathrm{~mm}$. 
of Lexovisaurus in that it is thicker and the basal region is not obliquely inclined. Moreover, the piece does not show the conspicuous ornamentation on the large plates of Stegosaurus, but this could be due to preservation. Further comparisons are difficult because of the fragmentary nature of the material.

The dermal armour of European stegosaurs is not well known (Galton, 1990a; Blows, 2001). Lexovisaurus is represented by both plates and spines (Galton, 1985, 1990b) whereas, apart from one small plate with a thick base (Galton, 1985: figs. 21M-O; part of holotype of Dacentrurus armatus), the dermal remains of Dacentrurus consist solely of spines (see Galton, 1991; Casanovas et al., 1995a). The Burgos specimen is not useful for systematic purposes but represents one of the few stegosaurian plates found to date in the Iberian Peninsula and in Europe.

Based on the available remains, a precise identification of the Burgos stegosaur is not possible. Thus, the material is here provisionally referred to the suborder Stegosauria as Stegosauria indet.

\section{REVIEW OF CRETACEOUS STEGOSAURS}

Early Cretaceous stegosaurs were less common and diverse than the Late Jurassic representatives of the group, but they had a worldwide distribution. Early Cretaceous stegosaurs are known from Europe, Asia and South America; moreover, their presence in Africa, Australia and North America has been suggested.

In Europe, two taxa are currently recognized from the Wealden rocks of England: Regnosaurus northamptoni Mantell, 1848, known from a partial lower jaw from the Valanginian of Sussex (see Barrett and Upchurch, 1995); and Craterosaurus pottonensis Seeley, 1874, based on an incomplete neural arch of a dorsal vertebrae from the Aptian (probably reworked from Valanginian deposits) of Bedfordshire (Galton, 1981). Regnosaurus and Craterosaurus may represent the same taxon but, because the two type specimens are not comparable with each other, the synonymy is not justified. A partial pubis, presumably from the Barremian of the Isle of Wight, is referred to the Stegosauria by Olshevsky (MS in prep., fig. 56). This referral is cited, without any discussion of specific characters, by Naish and Martill (2001: fig. 7.2), who give only a medial view. This does not show the laterally facing acetabular part of the pubis, so diagnostic of stegosaurs (Sereno, 1986), that is clearly seen in the original illustration by Hulke (1874: pl. 30, fig. 4 as "dinosaurian ilium", reidentified as an Iguanodon pubis in 1876). Other possible records of stegosaurs that have been reported from the Wealden succession of England include some isolated dermal plates from the Valanginian or Hauterivian of Sussex and, tentatively, the
Barremian of the Isle of Wight (Blows, 2001). In the Iberian Peninsula, Galton (1991) and Casanovas et al. (1995a, 1995b) have suggested that the distribution of Dacentrurus extended into the basal Cretaceous of Portugal and Spain, but this suggestion is currently based on controversial evidence (Casavovas et al., 1999; Pereda Suberbiola and Galton, 2001). Moreover, a dorsal plate, a tail spine and a partial rib of an indeterminate stegosaur found near Lourinhã, north of Lisbon, could be also placed either in the Tithonian or the Berriasian (Galton, 1994). Wealden stegosaur remains from the Early Cretaceous of Spain also include an isolated dermal spine from the Late Hauterivian of Galve, Teruel (Pereda Suberbiola and Galton, 2001) and, tentatively, vertebral remains from the upper Barremianbasal Aptian of Castellote, Teruel (Ruiz-Omeñaca, 2000).

Outside of Europe, Early Cretaceous stegosaurs are represented by a few taxa, most of them uncertainly dated. In Asia, Wuerhosaurus homheni Dong, 1973 is known from the ?Valanginian-Albian [probably Barremian; see Lucas and Estep, 1998; Averianov and Skutschas, 2000] of northwestern China (Dong, 1973); Wuerhosaurus ordosensis Dong, 1993 is though to come from the Early Cretaceous (probably Barremian; see Averianov and Skutschas, 2000) of Inner Mongolia (Dong, 1993); and Monkonosaurus lawulacus Dong, 1990 is from the Late Jurassic or Early Cretaceous of Tibet (Dong, 1990). Wiman (1929: fig. 7) described vertebral and dermal plate remains of an indeterminate stegosaur from the Early Cretaceous of the Meng-Yin Formation of Shandong, China. The age of this formation is controversial as it has been regarded either as Late Jurassic or Early Cretaceous (see Dong, 1992, 1995; Lucas and Estep, 1998 and references therein). In Africa, the report of a stegosaur-like femur from the Middle Cretaceous of Morocco is questionable because it is only based on a photograph (Russell, 1996, in Galton and Upchurch, in press). The partial skull of Paranthodon africanus (Broom, 1912) (see Galton and Coombs, 1981) comes from the Tithonian-Valanginian or Hauterivian of South Africa (Jacobs et al., 1996) [but Berriasian-Valanginian in Klerk et al., 2000]. Olshevsky (MS in prep.) noted the discovery of stegosaurian remains in the Early Cretaceous of Malawi, but this material has not yet been described and is not mentioned in the last review of African Cretaceous dinosaurs (Jacobs et al., 1996). In South America, indeterminate stegosaurid remains are known in the Hauterivian of Neuquén, Argentina (Bonaparte, 1995; Novas, 1997). Leonardi (1984) described possible stegosaurian footprints from the Early Cretaceous of Brazil, but these ichnites are probably of an iguanodontian (see Lockley and Hunt, 1998). In North America, Miller (1964) reported the discovery of Early Cretaceous stegosaurian remains in Arizona but, as far as known, this material is still undescribed. A footprint from the Early Cretaceous (Neocomian) of western Australia was identified as stegosaurian (Long, 1991; Dayton, 1991; 
Thulborn, 1997; Long, 1998: 130 for color photo). However, Page (1998) pointed out that the trackmaker may have been a sauropod rather than a stegosaur.

The most recent record may be the partial skeleton of the small stegosaur Dravidosaurus blanfordi Yadagiri and Ayyasami, 1979 from the Late Cretaceous (Coniacian) of southern India (Yadagiri and Ayyasami 1979; Galton, 1981; Maastrichtian stegosaur also mentioned but not described by Yadagiri and Ayyasami, 1979). However, Chatterjee and Rudra (1996; also Chatterjee 1997: 518) noted that they did not see the skull or plates and that the holotype may be based on a plesiosaur, fragments of which were found at the type locality, but they did not specifically reidentify any of the holotype bones. The skull and plates (Anonymous, 1978) are certainly not plesiosaurian but the holotype definitely needs to be redescribed.

\section{CONCLUSION}

Stegosaurian remains from the Early Cretaceous (Wealden strata; probably Hauterivian-Barremian) of Aldea del Pinar (Burgos, Spain) are represented by a dorsal vertebra and a partial dermal plate. The general form of the vertebra is reminiscent of that of the dorsal vertebrae of Dacentrurus, with a centrum that is even more massive than in this Late Jurassic form, but the material is too fragmentary for a generic identification. The dermal plate, one of the few stegosaurian plates described to date from Europe, is not useful for a more precise taxonomic attribution. Pending the discovery of new fossils, the Burgos remains are provisionally referred to as Stegosauria indeterminate.

This is the first report of stegosaurs in the region of Castilla y León (Spain) and one of the few pieces of evidences for the presence of this group of thyreophoran dinosaurs in the Early Cretaceous of Europe. Early Cretaceous stegosaurs are also known from Asia and South America; their presence in Africa, Australia and North America needs to be confirmed.

\section{ACKNOWLEDGEMENTS}

The authors are grateful to Carmelo García for taking the photographs and to Drs. Lourdes Casanovas and Angela Buscalioni for kindly reviewing the manuscript. The senior author acknowledges support from Programa Ramón y Cajal (Ministerio de Ciencia y Tecnología).

\section{REFERENCES}

Anonymous 1978. New dinosaurian remains. Geological Survey of India News, 9 (5), 4.
Averianov, A. and Skutschas, P. 2000. A eutherian mammal from the Early Cretaceous of Russia and biostratigraphy of the Asian Early Cretaceous vertebrate assemblages. Lethaia, 33, 330-340.

Barrett, P.M. and Upchurch, P. 1995. Regnosaurus northamptoni, a stegosaurian dinosaur from the Lower Cretaceous of southern England. Geological Magazine, 132, 213-222.

Beuther, A. 1966. Geologische untersuchungen in Wealden und Utrillas-Schichten in Westteil der Sierra de los Cameros (Nordwestliche Iberiche ketten), Spanien. Beihefte zum Geologischen Jahrbuch, 44, 103-121.

Blows, W.T. 2001. Possible stegosaur dermal armor from the Lower Cretaceous of southern England. In: The Armored Dinosaurs (Ed. K. Carpenter). Indiana University Press, Bloomington and Indianapolis, 130-140.

Bonaparte, J.F. 1995. Cretaceous tetrapods of Argentina. Münchner Geowissenschaftlichen Abhandlungen A, 30, 73-130.

Broom, R. 1912. Observations on some specimens of South African fossil reptiles preserved in the British Museum. Transactions of the Royal Society of South Africa, 2, 1925.

Carpenter, K., Miles, C.A. and Cloward, K. 2001. New primitive stegosaur from the Morrison Formation, Wyoming. In: The Armored Dinosaurs (Ed. K. Carpenter). Indiana University Press, Bloomington and Indianapolis, 55-75.

Casanovas, M.L., Santafé, J.V., Pereda Suberbiola, X. y Santisteban, C. 1995a. Presencia por primera vez en España de dinosaurios estegosaurios. Revista Española de Paleontología, 10, 83-89.

Casanovas, M.L., Santafé, J.V. y Santisteban, C. 1995b. Dacentrurus armatus (Stegosauria, Dinosauria) del Cretácico inferior de Los Serranos (Valencia, España). Revista Española de Paleontología, 10, 273-283.

Casanovas, M.L., Santafé, J.V. y Pereda Suberbiola, X. 1997. Nuevo material de estegosaurios en el Cretácico inferior de Valencia (Aras de Alpuente, localidad de Losilla I). Paleontologia i Evolució, 28-29 (1995), 269-274.

Casanovas, M.L., Santafé, J.V., Santisteban, C. y Pereda Suberbiola, X. 1999. Estegosaurios (Dinosauria) del Jurásico superior-Cretácico inferior de la Comarca de los Serranos (Valencia, España). Revista Española de Paleontología, $\mathbf{n}^{\circ}$ extr. Hom. Prof. J. Truyols, 57-63.

Chatterjee, S. 1997. 225 Million Years of Evolution. The Rise of Birds. John Hopkins University Press, Baltimore, $312 \mathrm{pp}$.

Chatterjee, S. and Rudra, D.K. 1996. KT events in India: Impact, rifting, volcanism and dinosaur extinction. $\mathrm{Me}$ moirs of Queensland Museum, 39, 489-532.

Clemente, P. and Pérez-Arlucea, M. 1993. Depositional architecture of the Cuerda del Pozo Formation. Lower Cretaceous of the extensional Cameros Basin, North-Central Spain. Journal of Sedimentary Petrology, 63, 437-452.

Dayton, L. 1991. Missing dinosaurs turn up in Australia. New Scientist, 131 (1783), 20.

Dong, Z. 1973. Dinosaurs from Wuerho. Memoires of the Institute of Vertebrate Paleontology and Paleoanthropology Academia Sinica, 11, 45-52 [in Chinese]. 
Dong, Z. 1990. Stegosaurs of Asia. In: Dinosaur Systematics: Perspectives and Approaches (Eds. K. Carpenter and P.J. Currie), Cambridge University Press, Cambridge, 255268.

Dong, Z. 1992. Dinosaurian Faunas of China. China Ocean Press, Beijing and Springer-Verlag, Berlin, 188 pp.

Dong, Z. 1993. A new species of stegosaur (Dinosauria) from the Ordos Basin, Inner Mongolia, People's Republic of China. Canadian Journal of Earh Sciences, 30, 21742176.

Dong, Z. 1995. The dinosaur complexes of China and their biochronology. In: Sixth Symposium on Mesozoic Terrestrial Ecosystems and Biota, Short Papers (Eds. A. Sun and Y. Wang). China Ocean Press, Beijing, 91-96.

Dong, Z., Li, X., Zhou, S. and Chang, Y. 1977. On the stegosaurian remains from Zigong (Tzekung), Zsechuan Province. Vertebrata PalAsiatica, 5, 307-312 [in Chinese].

Galton, P.M. 1981. Craterosaurus pottonensis Seeley, a stegosaurian dinosaur from the Lower Cretaceous of England, and a review of Cretaceous stegosaurs. Neues Jahrbuch für Geologie und Paläontologie Abh., 161, 28-46.

Galton, P.M. 1982. The postcranial anatomy of stegosaurian dinosaur Kentrosaurus from the Upper Jurassic of Tanzania, East Africa. Geologica et Palaeontologica, 15, 139-160.

Galton, P.M. 1985. British plated dinosaurs (Ornithischia, Stegosauridae). Journal of Vertebrate Paleontology, 5, 211-254.

Galton, P.M. 1990a. Stegosauria. In: The Dinosauria (Eds. D.B. Weishampel, P. Dodson and H. Osmólska). University of California Press, Berkeley, 435-455.

Galton, P.M. 1990b. A partial skeleton of the stegosaurian dinosaur Lexovisaurus from the uppermost Lower Callovian (Middle Jurassic) of Normandy, France. Geologica et Palaeontologica, 24, 185-199.

Galton, P.M. 1991. Postcranial remains of stegosaurian dinosaur Dacentrurus from the Upper Jurassic of France and Portugal. Geologica et Palaeontologica, 25, 299-327.

Galton, P.M. 1994. Notes on Dinosauria and Pterodactylia from the Cretaceous of Portugal. Neues Jahrbuch für Geologie und Paläontologie Abh., 194, 253-267.

Galton, P.M. and Coombs, W.P., Jr. 1981. Paranthodon africanus (Broom), a stegosaurian dinosaur from the Lower Cretaceous of South Africa. Geobios, 14, 299-309.

Galton, P.M. and Upchurch, P. In press. Stegosauria. In: The Dinosauria, $2^{\text {nd }}$ ed. (Eds. D.B. Weishampel, P. Dodson, P. and H. Osmólska). University of California Press, Berkeley.

Gilmore, C.W. 1914. Osteology of the armored Dinosauria in the United States National Museum, with special reference to the genus Stegosaurus. Bulletin of the United States National Museum, 89, 1-143.

Hennig, E. 1915. Kentrosaurus aethiopicus, der Stegosauridae des Tendaguru. Sitzungsberichte der Gesellschaft naturforschender Freunde Berlin, 1915, 219-247.

Hoffstetter, R. 1957. Quelques observations sur les stégosaurinés. Bulletin du Muséum National d'Histoire Naturelle de Paris, 29, 537-547.
Hulke, J.W. 1874. Note on a modified form of dinosaurian ilium, hitherto reputed scapula. Quarterly Journal of the Geological Society of London, 30, 521-528.

Hulke, J.W. 1876. Appendix to "Note on a modified form of dinosaurian ilium, hitherto reputed scapula." Quarterly Journal of the Geological Society of London, 32, 364-366.

Jacobs, L.L., Winkler, D.A. and Gomani, E.M. 1996. Cretaceous dinosaurs of Africa: examples from Cameroon and Malawi. Memoirs of Queensland Museum, 39, 595-610.

Klerk, W.J. de, Forster, C.A., Sampson, S.D., Chinsamy, A. and Ross, C.F. 2000. A new coelurosaurian dinosaur from the Early Cretaceous of South Africa. Journal of Vertebrate Paleontology, 20, 324-332.

Lapparent, A.F. de and Zbyszewski, G. 1957. Les Dinosauriens du Portugal. Serviços Geológicos de Portugal, Memorias N.S., 2, 1-63.

Leonardi, G. 1984. Le impronte fossili di Dinosauri. In: Sulle orme dei Dinosauri (Eds. J.F. Bonaparte, E.H. Colbert, P.J. Currie, A. de Ricqlès, Z. Kielan-Jaworowska, G. Leonardi, N. Morello e P. Taquet). Erizzo Ed., Venice, 165-186.

Lockley, M.G. and Hunt, A.P. 1998. A probable stegosaur track from the Morrison Formation of Utah. Modern Geology, 23, 331-342.

Long, J.A. 1991. Dinosaurs of Australia and other Animals of the Mesozoic Era. Reed Books, Sydney, 88 pp.

Long, J.A. 1998. Dinosaurs of Australia and New Zealand and other Animals of the Mesozoic era. Harvard University Press, Cambridge, 188 pp.

Lucas, F.A. 1902. Paleontological notes. The generic name Omosaurus. Science, 19, 435.

Lucas, S.G. and Estep, J.W. 1998. Vertebrate biostratigraphy and biochronology of the Cretaceous of China. In: Lower and Middle Cretaceous Terrestrial Ecosystems (Eds. S.G. Lucas, J.I. Kirkland and J.W. Estep). New Mexico Museum of Natural History and Science Bulletin, 14, 1-20.

Mantell, G.A. 1848. On the structure of the jaws and teeth of the Iguanodon. Philosophical Transactiuons of the Royal Society of London, 138, 183-202.

Marsh, O.C. 1877. New order of extinct Reptilia (Stegosauria) from the Jurassic of the Rocky Mountains. American Journal of Science, ser. 3, 14, 513-514.

Martín Closas, C. y Alonso Millán, A. 1998. Estratigrafía y bioestratigrafía (Charyophyta) del Cretácico inferior en el sector occidental de la Cuenca de Cameros (Cordillera Ibérica). Revista de la Sociedad Geológica de Espa$\tilde{n} a$, 11, 253-269.

Miller, H.W. 1964. Cretaceous dinosaur remains from southern Arizona. Journal of Paleontology, 38, 378-384.

Naish, D. and Martill, D.M. 2001. Armoured dinosaurs: Thyreophorans. In: Dinosaurs of the Isle of Wight (Eds. D.M. Martill and D. Naish). Palaeontological Association of London Field Guide to Fossils, 10, 147-184.

Nopcsa, F. 1911. Omosaurus lennieri, un nouveau dinosaurien du Cap de la Hève. Bulletin de la Société géologique de Normandie, 30, 23-42.

Novas, F.E. 1997. South American Dinosaurs. In: Encyclopedia of Dinosaurs (Eds. P. J. Currie and K. Padian). Academic Press, San Diego and London, 678-689. 
Olshevsky, G. in preparation. The origin and evolution of the stegosaurs. Historical Dinosaurology, 1, 1-124.

Ostrom, J.H. and McIntosh, J.S. 1966. Marsh's dinosaurs. The Collections from Como Bluff. Yale University Press, New Haven, 388 pp.; $2^{\text {nd }}$ ed., 1999, xxiv + 388 pp.

Owen, R. 1875. Monographs of the fossil Reptilia of the Mesozoic formations. Pt. II. Genera Bothriospondylus, Cetiosaurus, Omosaurus. Palaeontographical Society Monographs, 29, 15-94.

Page, D. 1998. Stegosaur tracks and the persistence of facies - the Lower Cretaceous of western Australia. Geology Today, 14, 75-77.

Pereda Suberbiola, X. and Galton, P.M. 2001. Thyreophoran ornithischian dinosaurs from the Iberian Peninsula. In: Actas de las I Jornadas Internacionales sobre Paleontología de Dinosaurios y su entorno (Eds. Colectivo Arqueológico-Paleontológico de Salas), Salas de los Infantes, Burgos, 147-161.

Platt, N.H. 1986. Sedimentology and tectonics of western Cameros Basin. Province of Burgos, Northern Spain. Thesis, University of Oxford, $125 \mathrm{pp}$. (unpublished)
Russell, D.A. 1996. Isolated dinosaur bones from the Middle Cretaceous of the Tafilalt, Morocco. Bulletin du Muséum national d'Histoire naturelle de Paris, 18, 349-402.

Ruiz-Omeñaca, J.I. 2000. Restos de dinosaurios (Saurischia, Ornithischia) del Barremiense superior (Cretácico inferior) de Castellote (Teruel) en el Muséum National d'Histoire Naturelle de París. Mas de las Matas, 19, 39-119.

Seeley, H.G. 1874. On the base of a large lacertilian cranium from the Potton Sands, presumably dinosaurian. Quarterly Journal of the Geological Society of London, 30, 690-692.

Sereno, P.C. 1986. Phylogeny of the bird-hipped dinosaurs. National Geographic Research, 2, 234-256.

Thulborn, R.A. 1997. Dinosaur tracks of the Broome Sandstone. Notes for a field excursion 28-29 June 1997. University of Queensland, Brisbane, 15 pp.

Wiman, C. 1929. Die Kreide-Dinosaurier aus Shangtung. Palaeontologia Sinica, ser. C, 6, 1-67.

Yadagiri, P. and Ayyasami, K. 1979. A new stegosaurian dinosaur from Upper Cretaceous sediments of south India. Journal of the Geological Society of India, 20, 521-530.

Manuscrito recibido: 25 de noviembre, 2002 Manuscrito aceptado: 10 de marzo, 2003 